\title{
Analysis of Runoff Curve Number Distribution into Surface Runoff of Lesti Watershed
}

\author{
Didit Priambodo $^{1^{*}}$, Ery Suhartanto ${ }^{2}$, Sumiadi $^{2}$ \\ ${ }^{1}$ Perum Jasa Tirta I, State Owned Corporation, Malang, East Java, 65145, Indonesia \\ ${ }^{2}$ Water Resources Engineering Department, Universitas Brawijaya, Malang, 65145, \\ Indonesia \\ didit_priambodo@jasatirta1.net \\ Received 09-01-2021; accepted 04-02-2021
}

\begin{abstract}
Lesti watershed is a sub basin of Brantas River located in Malang Regency, which is the main source of inflow and sediment loads for the Sengguruh Dam. Human activities change the type of land cover by deforestation for the expansion of agricultural and residential areas. It makes a rapid increasing of runoff and discharges that were potentially carrying sediment into Lesti River. To measure surface runoff in a watershed can be held by modeling rather than directly in the field, it is cheaper and more effective with accurate results. This study is based on Soil Conservation Service (SCS) formula to illustrate surface runoff level by knowing curve number distribution. Using models based on land use changes in 2010, 2012 and 2017, generated by AV SWAT software, shows that increasing $\mathrm{CN}$ value each year affects the surface runoff, so there is a relationship between land use and runoff. The average $\mathrm{CN}$ value in 2010 is 63.644 , 2012 is $63.942,2017$ is 65.49, while the average surface runoff in 2010 is $800.28,2012$ is 823.26 , 2017 is 828.009 . Conservation treatment on the area with a high $\mathrm{CN}$ value can reduce the surface runoff. It shows that watershed performance is getting better.
\end{abstract}

Keywords: curve number, Lesti watershed, runoff.

\section{Introduction}

Water flows naturally from a high to a lower area or its known as well as from upstream to downstream. In a hydrological system the water flow is divided into 4 sub-systems namely surface water, subregional groundwater, regional groundwater, and stream sub system. Rainfall is the most important component of the hydrological process. Rainfall depth is being transferred into stream, either through surface runoff, inter flow and sub surface flow or groundwater flow [1].

Erosion at upstream of watershed is a natural occurrence due to rainfall that reaches the ground surface where not full infiltrated into the soil [15]. In a good watershed, the erosion rate is small and can be held by an existing plant. And it is balanced with the rate of soil formation. But, since land use changes are not according to conservation principles, it is immediately increasing either the erosion rate and sedimentation in river and reservoir [2].

Cite this as: Priambodo, D., Suhartanto, E., \& Sumiadi. (2021). Analysis of Runoff Curve Number Distribution into Surface Runoff of Lesti Watershed. Civil and Environmental Science Journal (Civense), 4(1), 62-75. doi: https://doi.org/10.21776/ub.civense.2021.00401.6 
In recent years, land use in Lesti watershed has already changed. There was an increase in agricultural land and residential area, while the forest was decreasing. This change has an impact on runoff and river discharge whose value are getting higher and potentially occurs the erosion and sedimentation in Sengguruh reservoir [3]. According to Perum Jasa Tirta I data, the storage capacity of Sengguruh reservoir in 2011 has been reduced to $76,8 \%$ from its initial capacity [4].

Several recent studies $[3,5,6,7,8]$ have used hydrological models that reflect the relationship between rainfall and surface runoff by considering the condition of land cover which is one of the erosion factors. Soil Conservation Service (SCS) is one of hydrological model to calculate the prediction of surface runoff and curve number $(\mathrm{CN})$, which is a function of watershed characteristics such as land use, soil type, land cover, moisture, and land management methods.

This research conducted to analyze the relationship of surface runoff and discharge on Lesti watershed by creating the map of $\mathrm{CN}$ distribution value, and making an alternative model of improvement land use by conservation approach on Lesti watershed.

\section{Materials and Methods}

\subsection{Study Location}

This research uses the upstream Lesti River Basin as the area of study location. Lesti sub-catchment area is located in Malang Regency, East Java, Indonesia. Geographically, it is situated between $8^{\circ} 02^{\prime} 50^{\prime \prime}$ $-8^{\circ} 12^{\prime} 10^{\prime \prime}$ LS and $112^{\circ} 42^{\prime} 58^{\prime \prime}-112^{\circ} 56^{\prime} 21^{\prime \prime}$ BT. The Lesti watershed area is 58,294 Ha, divided into sub-catchment areas, Upstream Lesti with 38,248 Ha and Downstream Lesti in 20,046 Ha.

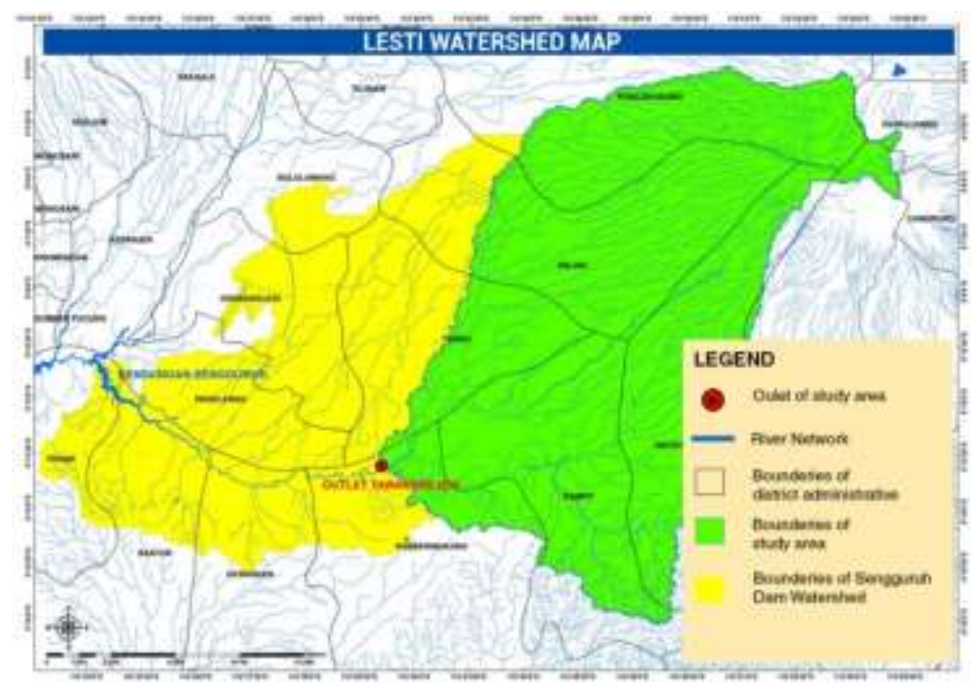

Figure 1. Location of Study

\subsection{Data and tools}

The study conducted some analysis using spatial data from Arc View GIS 10.3 process, such as sensing of land use, soil type, and $\mathrm{CN}$ distribution maps. This program has an extension to analyze the model of watershed management and its impact to hydrology response unit, erosion, and sedimentation that relate with soil type, land use, and land cover periodically. It is called AV SWAT 2000. The data structure used to run this program consists of two spatial types, vector and grid-based data.

Several data are used in this study, i.e.:

1. Topography map in scale $1: 25,000$ of Lesti Watershed

2. River network map in scale $1: 25,000$

3. Land use map year 2010, 2012, and 2017.

4. Soil type map of Lesti watershed 
5. Daily rainfall data in 20 years $(2000-2019)$

6. Tawangrejeni AWLR discharge data in 10 years (2010 -2019)

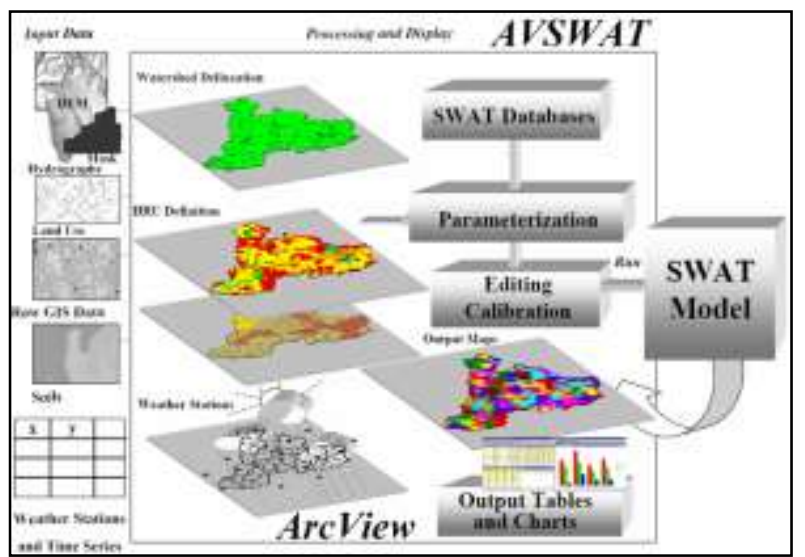

Figure 2. Data Structure Model in AV SWAT

To analyse the relationship of land use changes to runoff $\mathrm{CN}$, this research uses three models simulation for 3 years of Lesti watershed land use, 2010, 2012, and 2017.

\subsection{Research procedure}

The research method used is analytical research with stages as below:

1. Collect the data.

2. Analyse the hydrological aspects

3. Digitize the map

4. Running the hydrological, land use and soil type data using AV SWAT 2000 program, to result discharge model calculation.

5. Calibrate the model discharge with observation discharge from Tawangrejeni station AWLR.

6. Analyse $\mathrm{CN}$ value distribution map using output of calibrated model.

7. Analyse surface runoff of watershed for each model simulation.

8. Create alternatives of land use improvement simulation and analyse the $\mathrm{CN}$ and runoff value using the same process with the earlier model.

9. Analyse the comparison of each results simulation. Primary and secondary data collection

\subsection{Watershed}

A watershed has special characteristics related to land use, soil type, slope and its length and topography. Land use and slope are two factors that can be change by human, while the other factors are natural and uncontrol. Therefore, the land use change, slope, and land cover focus on watershed management [2]. Vegetation types are important in hydrological systems, and human intervention in this factor is enormous. Vegetation can affect soil physical and chemical characteristics to change soil surface condition and runoff value.

When rainfall intensity exceeds the infiltration capacity, water will fill the cavities on ground surface first. Then, the rest of water will flow over the ground or known as surface runoff. It will run into the trench or ditch, until it enters tributaries and collects as a river [1].

Volume and rate of surface runoff are depending on meteorology character of watershed. SCS are develop an index called runoff curve number that expresses the impact of soil condition, hydrology or water content simultaneously.

\subsection{Hydrology analysis}

The result of hydrological analysis is rainfall intensity in several period as input data for model development. 


\subsection{Soil Conservation Service (SCS)}

The SCS method is develop from rainfall observation for years and involve many agricultural areas in US. This method is based on relationship between infiltration for every soil type with every rainfall that reaches the ground. Total rainfall in every rain $(\mathrm{P})$ on the ground with maximum potential of soil retains water $(\mathrm{S})$, will divide into 3 components; runoff water $(\mathrm{Q})$, infiltration $(\mathrm{F})$ and initial abstraction (Ia), with formulas [9]

With:

$$
Q=\frac{\left(P-I_{a}\right)^{2}}{\left(P-I_{a}+S\right)}
$$

$\mathrm{Q}=$ Volume of surface runoff $(\mathrm{mm})$

$\mathrm{Ia}=$ Initial abstraction

$\mathrm{P}=$ Daily rainfall $(\mathrm{mm})$

$\mathrm{S}=$ Volume of total retention parameter $(\mathrm{mm})$

To determine depth excess rainfall or surface runoff can be showed on formula above, where correlation Ia with $\mathrm{S}$ is [9]:

$$
I_{a}=0.2 S
$$

To simplify calculation of antecedent moisture condition, land use, and soil conservation, US SCS determine $\mathrm{S}$ value as below:

$$
S=25.4\left(\frac{1000}{C N}-10\right)
$$

$\mathrm{CN}$ : runoff curve number $(0-100)$

By plotting $\mathrm{P}$ and $\mathrm{Q}$ in SCS curve (graphic below), it finds the $\mathrm{CN}$ value. In SCS, soil type is classified into 4 type based on the type and land use (hydrological soil group). Usually, initial abstraction use approach $0.2 \mathrm{~S}$. So, the formulas :

$$
Q=\frac{(P-0.2 S)^{2}}{(P+0.8 S)}
$$

Surface runoff will occurred when rain (P) is bigger than initial abstraction (Ia). For different CN value look this picture.

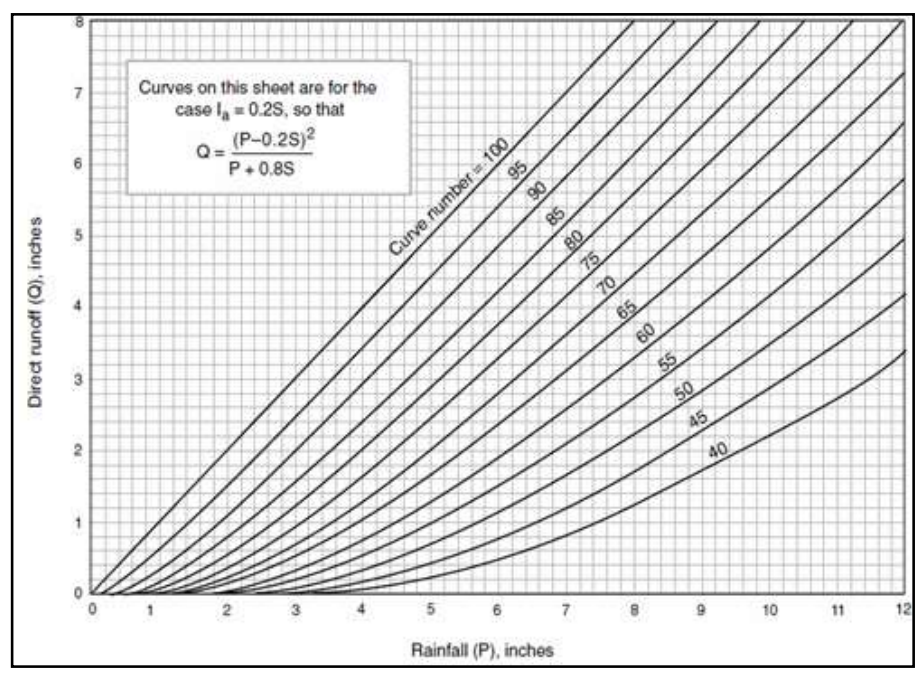

Figure 3. CN-SCS graphics 
$\mathrm{CN}$ value is obtained from area study which has moderate climate. But this value can be used, when there is no value determined in area study.

Table 1. CN value by SCS classification

\begin{tabular}{|c|c|c|c|c|}
\hline \multirow{2}{*}{$\begin{array}{l}\text { Land-use description } \\
\text { Cultivated land }^{1}:\end{array}$} & $A$ & $B$ & $C$ & $D$ \\
\hline & & & & \\
\hline without conservation treatment & 72 & 81 & 88 & 91 \\
\hline with conservation treatment & 62 & 71 & 78 & 81 \\
\hline \multicolumn{5}{|l|}{ Pasture or range land: } \\
\hline poor condition & 68 & 79 & 86 & 89 \\
\hline good condition & 39 & 61 & 74 & 80 \\
\hline Meadow: good condition & 30 & 58 & 71 & 78 \\
\hline \multicolumn{5}{|l|}{ Wood or forest land: } \\
\hline thin stand, poor cover, no mulch & 45 & 66 & 77 & 83 \\
\hline good cover2 & 25 & 55 & 70 & 77 \\
\hline \multicolumn{5}{|l|}{ Open spaces, lawn, parks, golf courses, cemeteries, etc. } \\
\hline good condition: grass cover on 75 percent or more of the area & 39 & 61 & 74 & 80 \\
\hline fair condition: grass cover on SO to 75 percent of the area & 49 & 69 & 79 & 84 \\
\hline Commercial and business areas ( 85 percent impervious) & 89 & 92 & 94 & 95 \\
\hline Industrial districts (72 percent impervious) & 81 & 88 & 91 & 93 \\
\hline \multicolumn{5}{|l|}{ Residential $^{3}$ : } \\
\hline Average percent impervious ${ }^{4}$ & & & & \\
\hline $1 / 8$ acre or less & 77 & 85 & 90 & 92 \\
\hline $1 / 4$ acre & 61 & 75 & 83 & 87 \\
\hline $1 / 3$ acre & 57 & 72 & 81 & 86 \\
\hline $1 / 2$ acre & 54 & 70 & 80 & 85 \\
\hline 1 acre & 51 & 68 & 79 & 84 \\
\hline 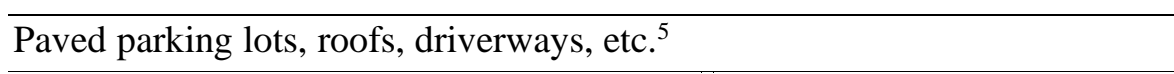 & 98 & 98 & 98 & 98 \\
\hline Street and roads: & & & & \\
\hline paved with curbs and storm sewers ${ }^{5}$ & 98 & 98 & 98 & 98 \\
\hline gravel & 76 & 85 & 89 & 91 \\
\hline dirt & 72 & 82 & 87 & 89 \\
\hline
\end{tabular}

The Antecedent Moisture Conditions (AMC) have strong influence on assessing surface runoff volume. Therefore, SCS has compiled three level of AMC based on the amount of rain in 5 days earlier [12]:

1. AMC I. Soil in watershed is dry, lowest potential runoff, however it is not to the point of withering, have been planted with good results. AMC I analysis is used to analyse CN when dry season.

2. AMC II. Soil is in average condition.

3. AMC III. Heavy or light rain with low temperature, soil is in saturated condition, and highest potential runoff. AMC III is used to analyse $\mathrm{CN}$ when wet season.

Curve Number value is equivalent on AMC I and III conditions can be counted by using this equation [10] : 
and,

$$
C N_{(I)}=\frac{4.2 C N_{(I I)}}{10-0.058 C N_{(I I)}}
$$

$$
C N_{(I I I)}=\frac{23 C N_{(I I)}}{10-0.13 C N_{(I I)}}
$$

SCS has developed soil classification system based on soil characteristic and that are classified into four Hydrologic Soil Group (HSG), i.e :

\begin{tabular}{|c|c|c|c|}
\hline $\mathrm{HSG}$ & Soil Texture & $\begin{array}{c}\text { HSG definitions } \\
\text { (USDA-NRCS, 1986) }\end{array}$ & $\begin{array}{l}\text { The six types of soil } \\
\text { textures in study area }\end{array}$ \\
\hline A & $\begin{array}{l}\text { Sand, loamy sand, or } \\
\text { sandy loam }\end{array}$ & $\begin{array}{l}\text { Low runoff potential and high } \\
\text { infiltration rates; This soils have high } \\
\text { rate of water transmission (greater than } \\
7.62 \mathrm{~mm} / \mathrm{hr} \text { ) }\end{array}$ & $\begin{array}{l}\text { (1) Loamy Sand (LS) } \\
\text { (2) Sandy Loam (SL) }\end{array}$ \\
\hline B & Silt loam or loam & $\begin{array}{l}\text { Moderate infiltration rates; The soils } \\
\text { have moderate rate of eater } \\
\text { transmission }(3.81 \mathrm{~mm} / \mathrm{hr})\end{array}$ & (3) Loam (LL) \\
\hline $\mathrm{C}$ & Sandy clay loam & $\begin{array}{l}\text { Low infiltration rates; The soils have a } \\
\text { low rate of water transmission }(1.27- \\
3.81 \mathrm{~mm} / \mathrm{hr})\end{array}$ & \\
\hline $\mathrm{D}$ & $\begin{array}{l}\text { Clay loam, silty clay } \\
\text { loam, sandy clay, } \\
\text { silty clay, or clay }\end{array}$ & $\begin{array}{l}\text { High runoff potential; These soils have } \\
\text { very low rate of water transmission }(0- \\
1.27 \mathrm{~mm} / \mathrm{hr})\end{array}$ & $\begin{array}{l}\text { (4) Clay Loam (CL) } \\
\text { (5) Heavy Clay (HC) } \\
\text { (6) Light Clay (LC) }\end{array}$ \\
\hline
\end{tabular}

Table 2. Hydrologic Soil Group Classification

\subsection{Land use direction}

To conduct a good land use, several criteria are determined for protecting forest and production forest according the watershed physical characteristic, such as land slope, soil type, sensitivity to erosion and response to daily rainfall. The criteria used in determining the area based on its function refer to Indonesian Government Regulation : PP No. 37/2012 and Minister of Forestry Regulation : P.60/Menhut-II/2014.

\section{Results and Discussion}

\subsection{Digitalize the catchment Area}

Initial process on AV SWAT program is to determine the watershed boundaries. By using topographic map and river network map, it can generate the digitized stream network with DEM format. Next step is to define the river and outlet location. This process needs data input for designated watershed outlet at the Tawangrejeni bridge and area threshold value of 500 ha. The result of this analysis are boundary of catchment area and river network of Lesti Watershed.

\subsection{Irrigation Performance Index Calculation}

- Analysis of Homogenous Rainfall

Based on the analysis using Raps Method, with $\mathrm{Q} / \sqrt{n}_{\mathrm{n}}$ calculation $<\mathrm{Q} / \sqrt{\mathrm{n}}_{\mathrm{n}}$ table and $\mathrm{R} / \sqrt{n}_{\mathrm{n}}$ calculation $<\mathrm{R} / \sqrt{\mathrm{n}}$ table, the rainfall data from Tangkil, Poncokusumo, and Dampit station is worth to use.

- Analysis of abnormality

Based on the analysis of Inlier-Outlier all rainfall data is within range from $\mathrm{Xh}$ to $\mathrm{Xl}$.

- Analysis of Consistency Rainfall

This analysis using Double Mass Curve methode. The result of this analysis are R2 for each station. There are $0.989,0.984$, and 0.994 . So, the rainfall data are consistent. 


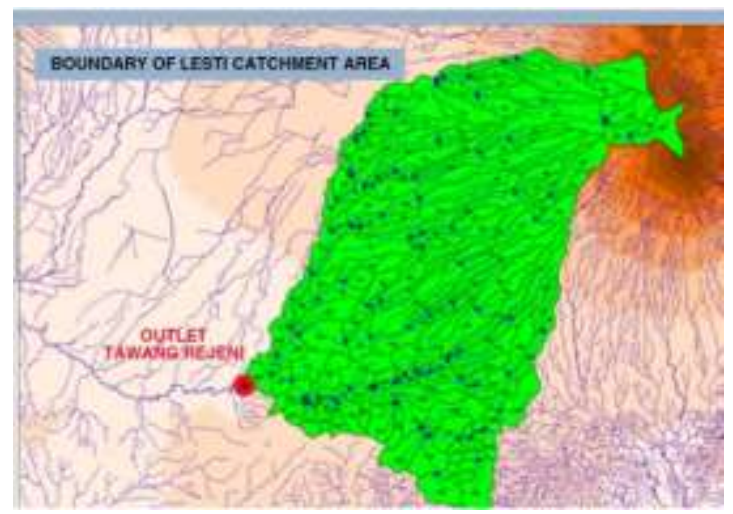

Figure 4. The boundary of Lesti Catchment Area with Tawangrejeni station as the outlet.

\subsection{Analysis of Land Slope}

By calculating watershed proses on AV SWAT program, land slope distribution is recorded on a dbf watershed table.

\begin{tabular}{|c|c|c|c|c|c|c|c|c|c|c|c|c|c|}
\hline \multicolumn{14}{|c|}{ 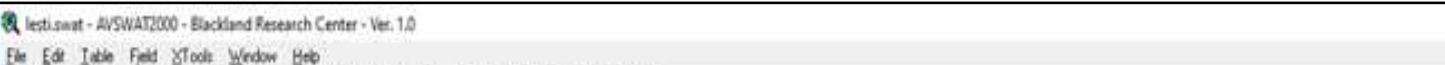 } \\
\hline$\square$ & d & 178 wedester & 1 & , & (0) & & & & & & & & \\
\hline \multicolumn{14}{|c|}{ 3. Aaributes al Sabbrint } \\
\hline shere & \begin{tabular}{l|l|l|}
4 \\
\end{tabular} & Gatase & semen & Ares & $\mid$ |n! & Sका & $s$ & a & HES & Ded & Loflide & Eko & Dhase \\
\hline Podpon & T & 3 & 3 & 358444 & 10058072 & 26806 & 00500 & 168008 & 86590 & 0,0002 & 8064948 & 30600 & \\
\hline Polpon & 5 & 11 & t1 & 228101 & 7652004 & 101400 & 35564 & 57739 & 05375 & 00820 & 8060276 & 74900 & \\
\hline Poxpon & 6 & 1 & 1 & 2851259 & $5 / 313251$ & 507804 & 00500 & 145846 & 24100 & 0197 & ACS6BO? & 143300 & \\
\hline Potpon & 7 & 10. & 10. & 1690001 & 30055004 & 17.4506 & 18.2207 & 115889 & 1630 & 0.1585 & 80585829 & $\$ 400$ & \\
\hline Polyon & 8 & 9. & 9 & 1230114 & 27302213 & 61505 & 609756 & 5557 & 1.4500 & 01412 & 8006895 & 00500 & \\
\hline Podpon & 9 & 5 & 5 & $500+008$ & 45625334 & 45009 & 00500 & $x 0000$ & 33353 & 0267 & 8061621 & 20200 & \\
\hline Polyon & $10^{\circ}$ & $8:$ & 6. & 1653730 & 3426707 & 484512 & 0050 & 345075 & $t 7445$ & 0150 & 8067763 & 227400 & \\
\hline Potpon & 11 & 4 & 4 & 6087872 & 75586974 & 39102 & 0050 & $20 \operatorname{css} 9$ & 33424 & 02452 & cosset4 & $18 \times 100$ & \\
\hline Polyon & 17 & 20 & 20 & 2000300 & 30528562 & 485014 & 00000 & 32792 & 19072 & 0.1722 & 807932 & 230300 & \\
\hline Poipon & 18 & 16. & 16. & 459237 & $40 \times \times 61$ & topose & 65054 & 3000 & $3 \times 16$ & 02613 & 860\%515i & 5900 & \\
\hline Fotown & 19 & 21 & 21 & $5 \pi 0 \times$ & 249774 & 51.1365 & 00500 & 372291 & 02313 & 0.413 & $8 \cos 349$ & $15 \times 0$ & \\
\hline Polpon & 20 & 12 & 12 & 439005 & $560 x=00$ & 900514 & 69986 & 50844 & $31 M$ & 0.2381 & 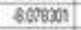 & $\infty 1, \infty$ & \\
\hline Polorn & 21 & 2 & 2 & 3160024 & $4625 \times 2$ & 457281 & 00500 & 310644 & 25738 & 0.2060 & $80011 \pi$ & 247300 & \\
\hline
\end{tabular}

Figure 5. Display of.$d b f$ Watershed Table in AV SWAT program to shows the land slope

\subsection{Analysis of Land Use Map}

Distribution of land use in the sub-catchment area presented in table 3.

Table 3. Distribution of land use in 2010, 2012, 2017

\begin{tabular}{|c|c|c|c|c|c|c|}
\hline \multirow{2}{*}{ Land Use } & \multicolumn{2}{|c|}{2010} & \multicolumn{2}{|l|}{2012} & \multicolumn{2}{|l|}{2017} \\
\hline & Area (ha) & $(\%)$ & Area (ha) & $(\%)$ & Area (ha) & $(\%)$ \\
\hline Shrubs & 566.01 & 1.48 & 503.26 & 1.32 & 470.16 & 1.23 \\
\hline Forest & $9,129.94$ & 23.87 & $8,670.69$ & 22.67 & $8,438.75$ & 22.00 \\
\hline Plantation & $3,199.18$ & 8.36 & $1,044.12$ & 2.73 & $1,014.31$ & 2.65 \\
\hline Residence & $1,642.94$ & 4.30 & $2,578.52$ & 6.74 & $6,242.09$ & 16.32 \\
\hline Moor & $17,598.49$ & 46.01 & $14,044.64$ & 36.72 & $12,182.62$ & 31.85 \\
\hline Agriculture & $6,069.12$ & 15.87 & $11,376.17$ & 29.74 & $9,873.70$ & 25.82 \\
\hline Fallow & 42.01 & 0.11 & 30.23 & 0.08 & 26.00 & 0.07 \\
\hline Total & $38,247.63$ & 100.00 & $38,247.63$ & 100.00 & $38,247.63$ & 100.0 \\
\hline
\end{tabular}


The tables show that there are land use changes each years. Forest, shrubs, and plantation are decreasing from $25.35 \%$ in 2010 to $23.99 \%$ in 2012 and $23.29 \%$ in 2017 . While the agriculture area are increasing from $15.87 \%$ in 2010 to $29.74 \%$ in 2012, and $25.84 \%$ in 2017 . Residence are also increasing from $4.3 \%$ in 2010 to $16.32 \%$ in 2017. Distribution of land use can be shown in spatial mode by mapping it.

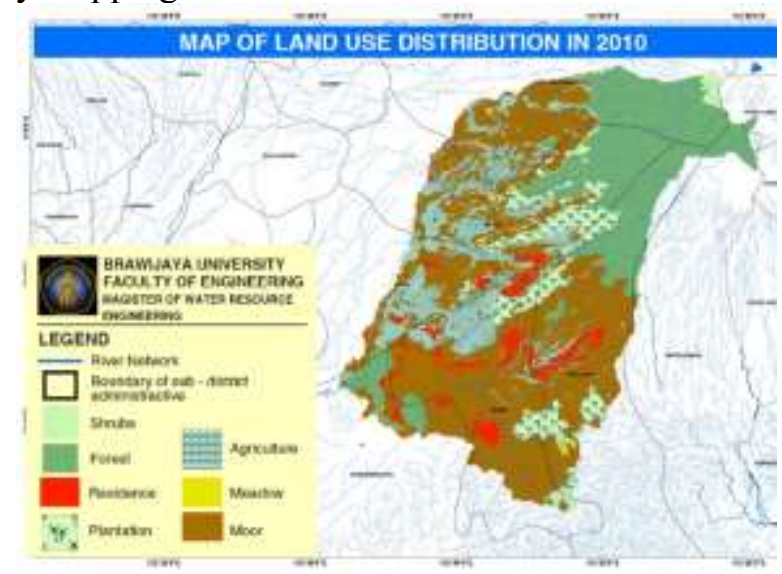

Figure 6. Map of Land Use Distribution in 2010

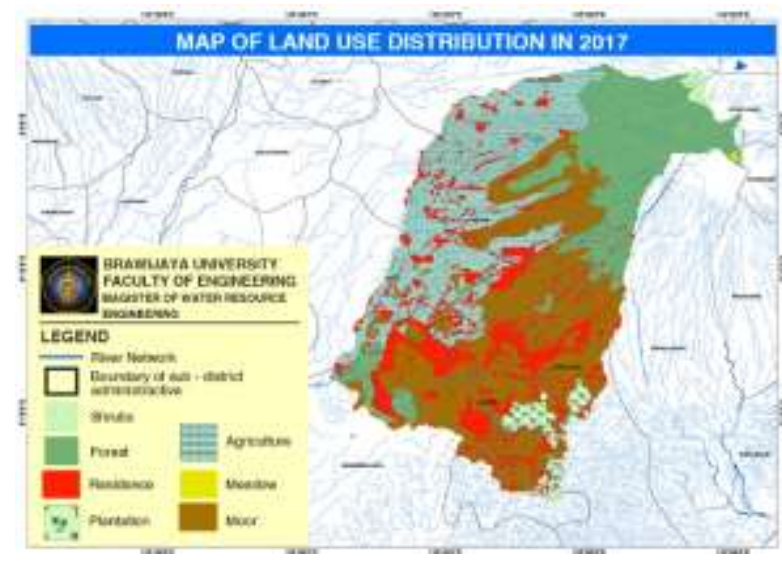

Figure 8. Map of Land Use Distribution in 2017

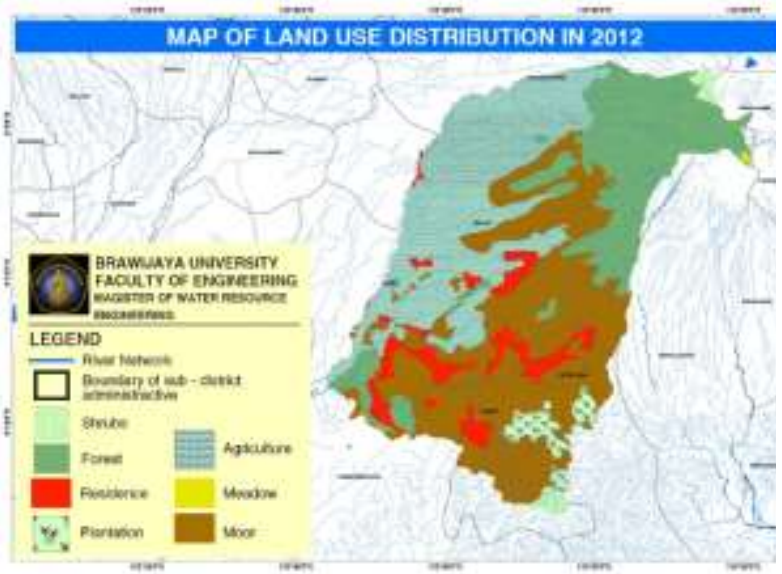

Figure 7. Map of Land Use Distribution in 2012

\begin{tabular}{cccccc}
\hline \multirow{2}{*}{ No. } & \multirow{2}{*}{ Land Use } & \multicolumn{4}{c}{ CN II Value } \\
\cline { 3 - 6 } & & $\mathrm{A}$ & $\mathrm{B}$ & $\mathrm{C}$ & $\mathrm{D}$ \\
\hline 1 & Water & 49 & 69 & 79 & 84 \\
\hline 2 & Forest & 36 & 60 & 73 & 79 \\
\hline 3 & Plantation & 43 & 65 & 76 & 82 \\
\hline 4 & Residence & 49 & 69 & 79 & 84 \\
\hline 5 & Meadow & 39 & 61 & 74 & 80 \\
\hline 6 & Agriculture & 58 & 69 & 77 & 80 \\
\hline 7 & Shrubs & 35 & 56 & 70 & 77 \\
\hline 8 & Moor & 43 & 65 & 76 & 82 \\
\hline \multicolumn{7}{c}{} & & & &
\end{tabular}

\subsection{Rehabilitation of Physical Infrastructure in Surak Irrigation Area}

HRU distribution is used to determine the area of land use and soil type in the watershed model.

\subsection{Rehabilitation of Physical Infrastructure in Surak Irrigation Area}

This simulation aims to process all data to obtain discharge and surface runoff value in the area studies. In this research, hydrological spatial modeling's simulation process uses scenarios land use modeling in 2010, 2012 and 2017. There are 2 types of AV SWAT 2000 simulation results files: Subbasin output file (*.sbs) and Main channel output file (*.rch)

\subsection{Rehabilitation of Physical Infrastructure in Surak Irrigation Area}

To obtain applicable and acceptable model in accordance with field conditions, a calibration step is required for the SWAT model. The calibration process is needed to adjust the influencing parameters in the study area's watershed so that the modeling results are closer to the observation discharge, in this case AWLR Tawangrijeni. In this study, the calibrated parameters are limited to LAT_TIME, CN, ESCO, SOL_AWC, and ALPHA_BF parameters. 
Table.5 AV SWAT 2000 Parameters Calibrated

\begin{tabular}{cccc}
\hline Parameter & Lower Limit & Upper Limit & Calibrated Value \\
\hline CN2 & 35 & 98 & $15 \%$ lower \\
\hline SOL_AWC & 0 & 1 & 0.05 \\
\hline ESCO & 0 & 1 & $0.4-0.5$ \\
\hline LAT_TIME & 0 & 270 & $170-180$ days \\
\hline ALPHA_BF & 0 & 1 & $0.55-0.75$ \\
\hline
\end{tabular}

The calibration process result is shown in the comparison graph for each modeling simulation in Figure. 10,11 and 12. Calibrated model is tested statistically to compare the data population, both model discharge and AWLR data. In this study, statistic testing uses regression method, Nash Sutcliff Efficient Method, and Mean Square Error Method. The results of all tests prove that the model is suitable for use.

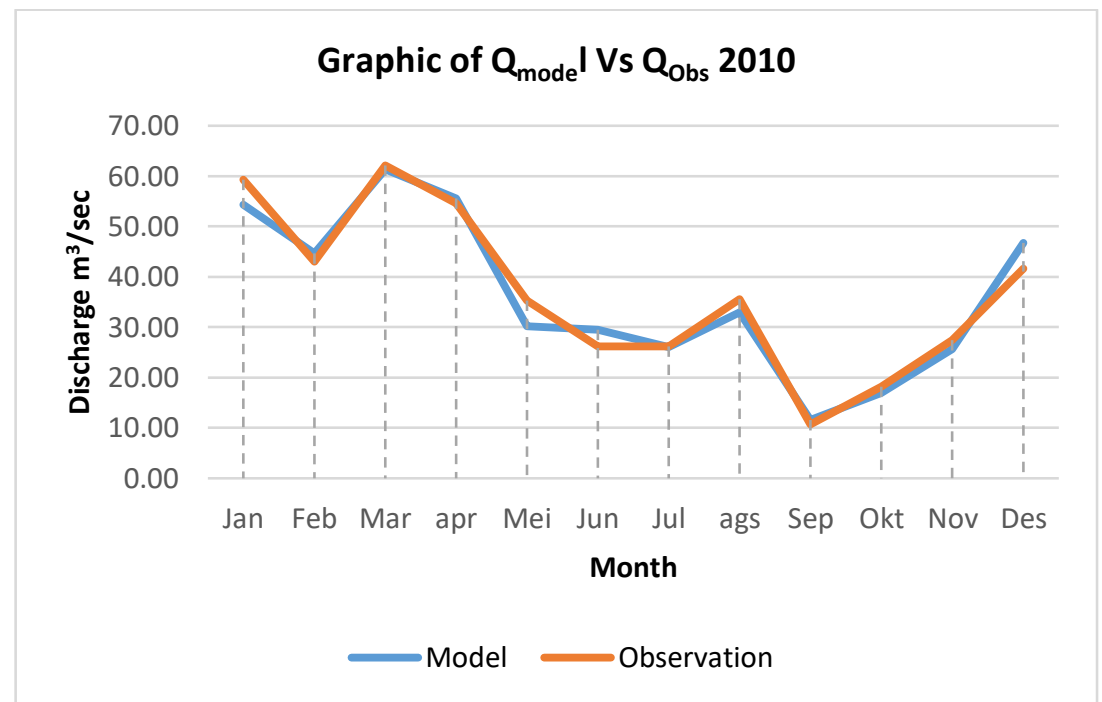

Figure 9. Comparation Graph of model discharge to AWLR discharge in 2010.

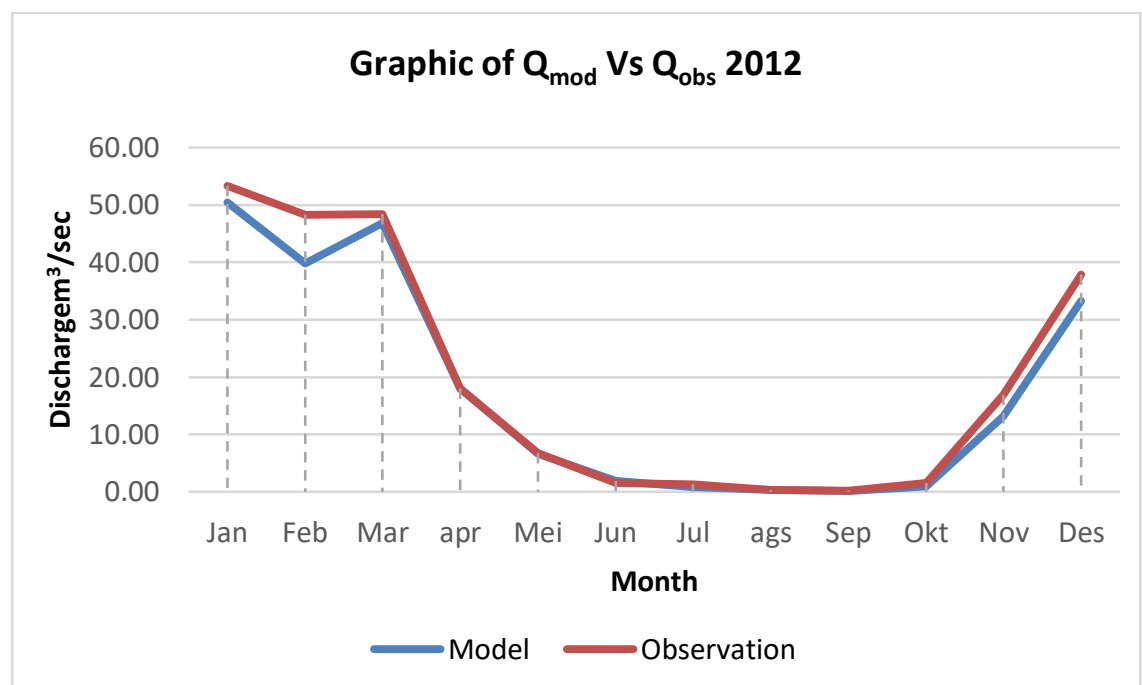

Figure 10. Comparation Graph of model discharge to AWLR discharge in 2012. 


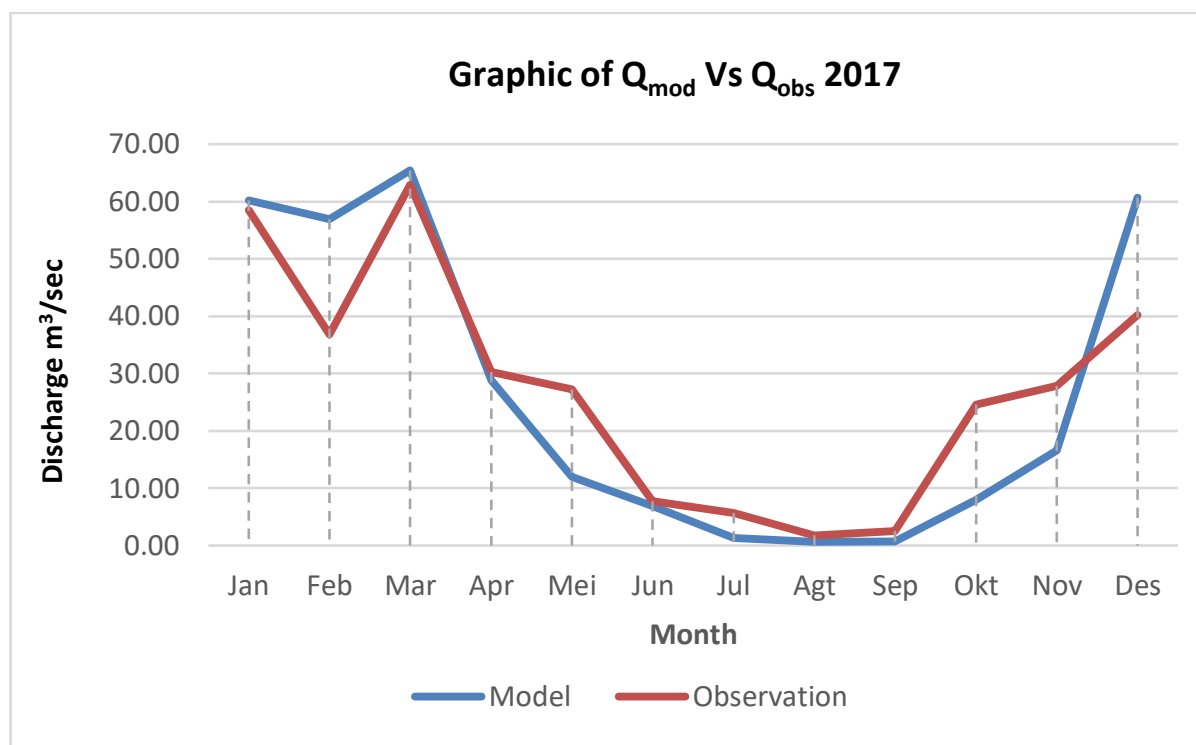

Figure 11. Comparation Graph of model discharge to AWLR discharge in 2017.

\subsection{Rehabilitation of Physical Infrastructure in Surak Irrigation Area}

One of the simulation outputs with calibrated parameter values is $\mathrm{CN}$ values for each sub basins and HRU. There are 176 sub basins in the model simulations divided by land use, soil type, and land management into each Hydrology Response Units. Each HRU has its own $\mathrm{CN}$ value obtained from running the AV SWAT program. By calculating each total HRU area's percentage factor, it can be obtained the average $\mathrm{CN}$ value for both sub-basin and watershed. The average $\mathrm{CN}$ value for each models are 63.44 in 2010, 63.94 in 2012, 65.49 in 2017.

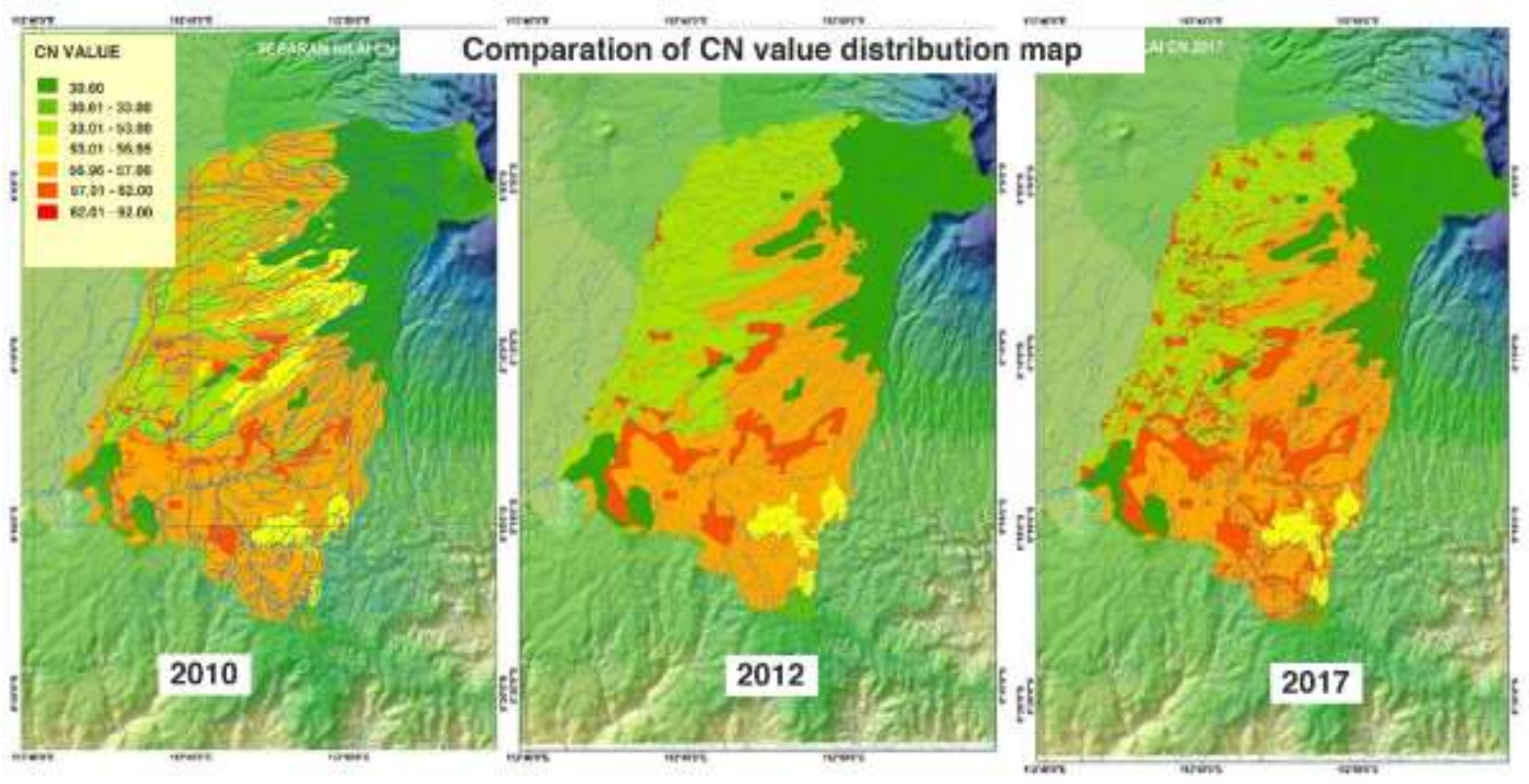

Figure.12 Comparation of CN value distribution map in 2010, 2012, and 2017 models.

From that spatial models (figure 12) are known, there are changes of $\mathrm{CN}$ values distribution that simultaneously with surface runoff rate changes. The increasing of agriculture area from 2010 to 2012 is more than 5,000 ha. Furthermore increasing of residence area from 2010 to 2017 are quite significant, 
is more than $4,500 \mathrm{ha}$. Otherwise, the area of forest and plantations continued to decline to nearly 3,000 ha in 7 years. It affects higher $\mathrm{CN}$ value in the following year.

\subsection{Rehabilitation of Physical Infrastructure in Surak Irrigation Area}

The results of model simulation using calibrated parameter values obtained the watershed rate of surface runoff distribution value. Mapping of the surface runoff distributions in each models are shown in Figure. 14, 15 and 16.

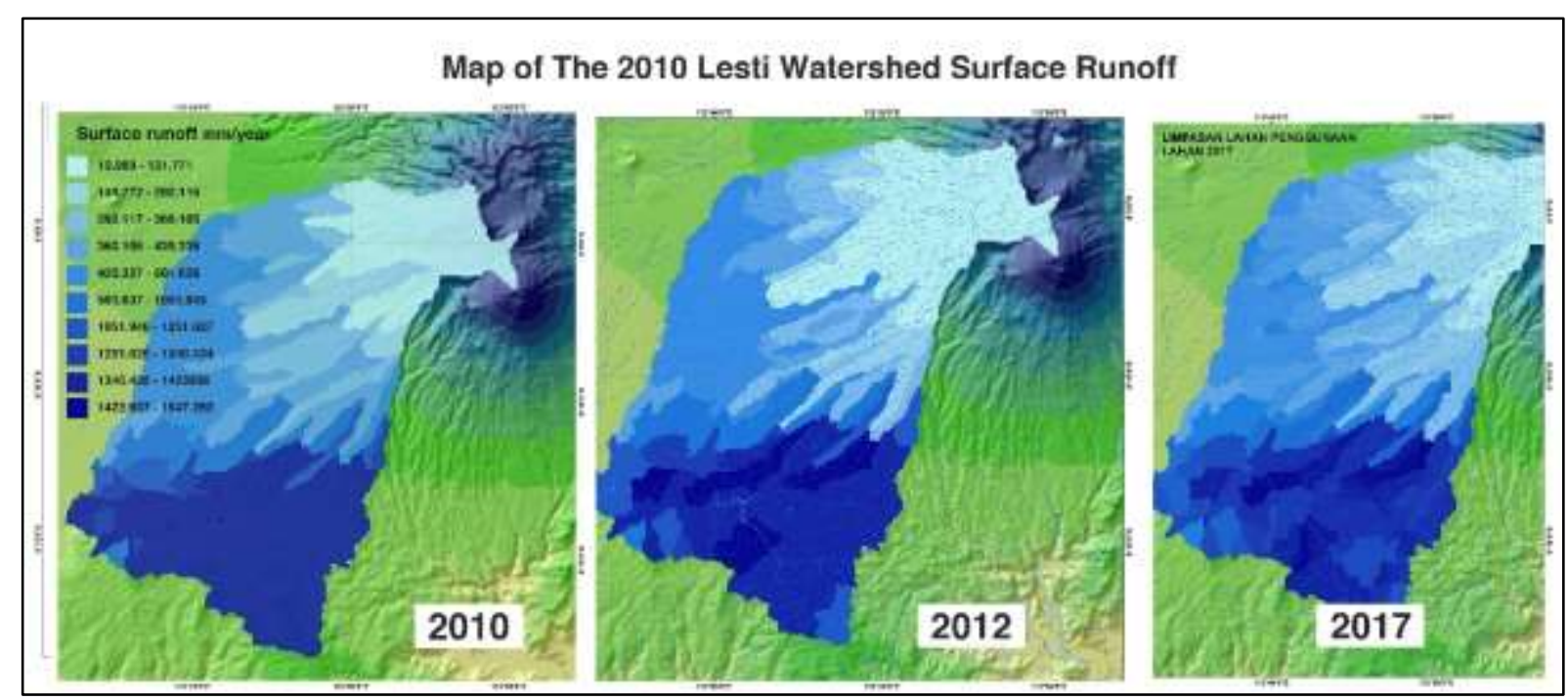

Figure 13. Map of The 2010 Lesti Watershed Surface Runoff

According to the figures above, there is an increasing of surface runoff values from 2010 to 2017. The average surface runoff in 2010 is $800.28 \mathrm{~mm} /$ year, 2012 is $823.26 \mathrm{~mm} /$ year, and 2017 is 828.009 $\mathrm{mm} /$ year. Surface runoff rates and watershed outlet river discharge also be measured as an evaluation of the $\mathrm{CN}$ Value.

Table 6. Comparation of hydrological value in Lesti Watershed

\begin{tabular}{|c|c|c|c|c|}
\hline Parameter & Units & 2010 & 2012 & 2017 \\
\hline$Q_{\min }$ & $\mathrm{m}^{3} / \mathrm{s}$ & 11.59 & 0.12 & 0.64 \\
\hline $\mathrm{Q}_{\max }$ & $\mathrm{m}^{3} / \mathrm{s}$ & 61.35 & 50.44 & 60.71 \\
\hline Runof & $\mathrm{mm} /$ year & 800.28 & 823.26 & 828.01 \\
\hline Avrg CN Vall & - & 63.44 & 63.94 & 65.49 \\
\hline
\end{tabular}

\subsection{Rehabilitation of Physical Infrastructure in Surak Irrigation Area}

Conservation efforts aim to improve the watershed ability to store the rainfall to reduce the surface runoff. The land improvement proposed through rearrangement the watershed existing land use (2017). The treatment priority are on sub basin or HRUs which have high $\mathrm{CN}$ values.

This study proposes two alternative conservation scenarios. First alternative is changing the land use of moor area with plantation with dense plants. The type of vegetation is also important. Sengon, Jabon, and fruit tree like Durian, Lamtoro, Kemiri, Avocado, and Jackfruit tree are highly recommended for use. Other treatment is adding $0.5 \mathrm{Ha}$ infiltration pond in the residence area by putting some infiltration wells in each house, making a wetland designed as a town park, and building some pond. Treatment of alternative I conservation scenario as seen on Figure 14. 


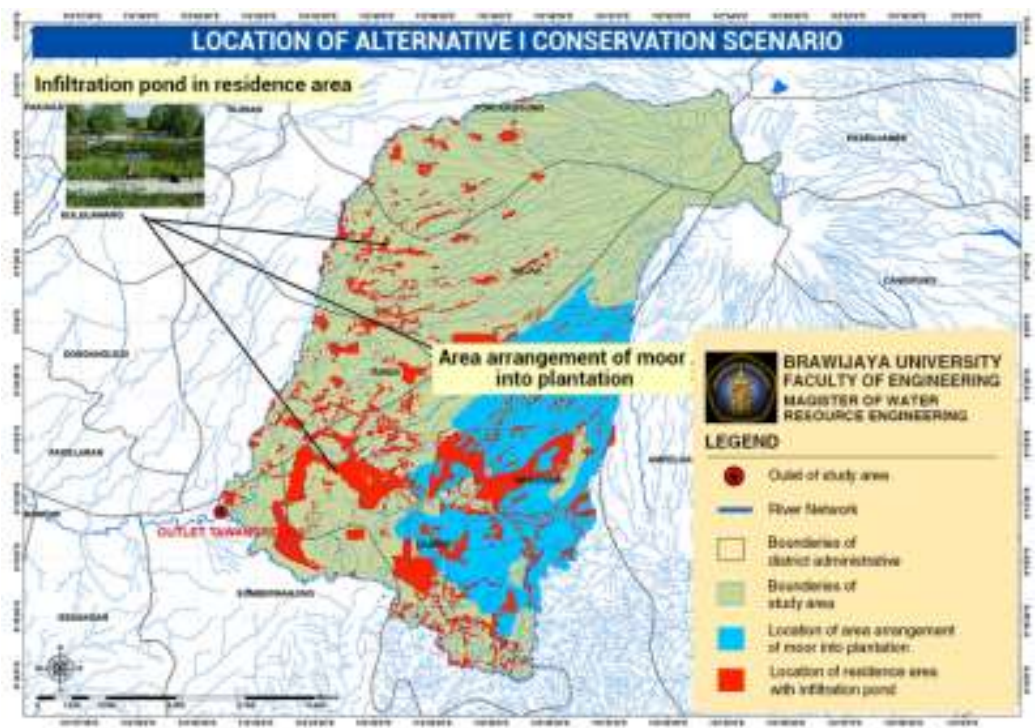

Figure 14. Location of Alternative I Conservation Scenario.

Second alternative is designed by keep the existing land use. Conservation effort are carried out through land treatment by changing the straight row crops into contoured fields or terraces (figure 15). The hydrologic effect of contouring results from the surface storage provided by the furrows because the storage prolongs the time during which infiltration can take place. The magnitude of storage depends not only on the dimensions of the furrows but also on the land slope, crop, planting and cultivation manner.

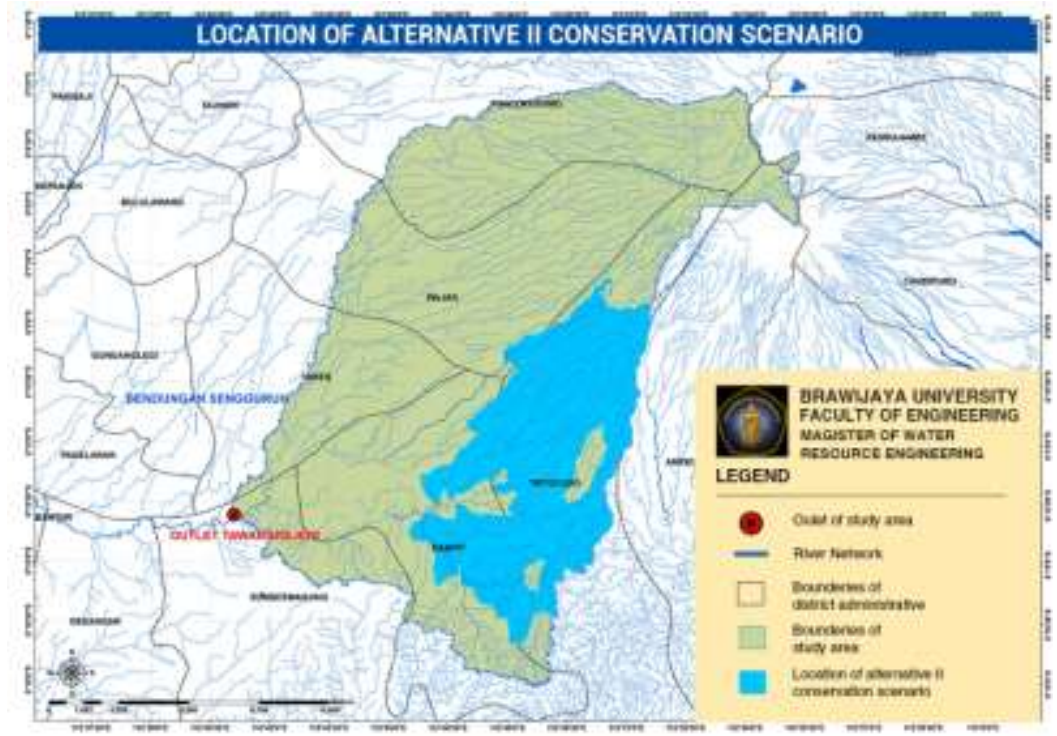

Figure 15. Location of Alternative II Conservation Scenario

Both conservation model simulations are run by changing the CN value of 2017's model, especially on the areas selected for conservation. The changes of CN Value are refer to the table of SCS CN classification.

\subsection{Rehabilitation of Physical Infrastructure in Surak Irrigation Area}

Both of conservation models are obtain similar simulation results (Table 7). 
Table 7. Comparison Of Watershed Hydrology Parameter

\begin{tabular}{llllll}
\hline Parameter & $\mathbf{2 0 1 0}$ & $\mathbf{2 0 1 2}$ & $\mathbf{2 0 1 7}$ & $\begin{array}{l}\text { Conservation } \\
\text { Alt I }\end{array}$ & $\begin{array}{l}\text { Conservation } \\
\text { Alt II }\end{array}$ \\
\hline $\mathrm{Q}_{\min }\left(\mathrm{m}^{3} / \mathrm{sec}\right)$ & 11.59 & 0.12 & 0.64 & 0.85 & 1.64 \\
\hline $\mathrm{Q}_{\max }\left(\mathrm{m}^{3} / \mathrm{sec}\right)$ & 61.35 & 50.44 & 60.71 & 39.55 & 39.88 \\
\hline Runoff Rate & 800.28 & 823.26 & 828.01 & 796.89 & 797.87 \\
\hline Averg CN Value & 63.44 & 63.94 & 65.49 & 64.27 & 62.75 \\
\hline
\end{tabular}

Both of conservation models are proven can reduce $\mathrm{CN}$ value, runoff rate, and outlet discharge in Lesti watershed. It means that the conservation models are successful and can be used to improve the watershed performance.

\section{Conclusion}

To predict the CN value of Lesti watershed, AV SWAT software analysis is used based on SCS formulas. There are three model scenarios with different years of land use, 2010, 2012, and 2017. Each models are calibrated with watershed outlet discharge obtained from Tawangrejeni AWLR data. The results of calibration is tested by Nash Sutcliff Efficient Method, and Mean Square Error Method. From all tests are proof that the model is suitable for use. Average $\mathrm{CN}$ values for each model are 63.44 in $2010,63.94$ in 2012, and 65.49 in 2017, with a 0.264 /year growth rate. Spatially, the increasing of CN values mostly occurred in the southern and western part of the watershed. It happened because of land use changes such as forest reduction, expansion of agricultural area, and rise of residence area.

The increasing of $\mathrm{CN}$ value each years affects on increase of surface runoff rate. The average surface runoff in 2010 is $800.28 \mathrm{~mm} /$ year, 2012 is $823.26 \mathrm{~mm} / \mathrm{year}$, and 2017 is $828.009 \mathrm{~mm} /$ year. It proves that changes in land cover and land management affects the watershed ability to storage the rainfall. When rainfall intensity exceeds the infiltration capacity, water will fill the cavities on a ground surface first. lit can change runoff value

Conservation treatment is needed to improve watershed ability to store the rainfall, reducing the surface runoff. In this study, there are two alternative scenarios. Alternative one is designed by change some land use of sub basin and adding ponds of infiltration on residence area. Alternative two is designed by keep the land use, and change the land cover and land management with lower $\mathrm{CN}$ value. The conservation simulation results are $\mathrm{CN}$ value is $64.27 \mathrm{for}$ an alternative I and 62.75 for an alternative II. While the rate of surface runoff for alternative I is $796.89 \mathrm{~mm} /$ year and for alternative II is 797.873 $\mathrm{mm}$ /year. It means that the conservation models are successful and can be used to improve the watershed performance.

\section{References}

[1] B. Triatmodjo, Hidrologi Teknik Terapan, Yogyakarta: Beta Offset, 2010.

[2] C. Asdak, Hidrologi dan Pengelolahan Daerah Aliran Sungai, Yogyakarta: Gajah Mada University Press, 2002.

[3] L.F. Ideawati, L.M. Limantara, and U. Andawayanti. "Analisis Perubahan Bilangan Kurva Aliran Permukaan (Runoff Curve Number) Terhadap Debit Banjir Di Das Lesti," Journal Of Water Resources Engineering. Vol. 6, No. 1, 2015.

[4] Perum Jasa Tirta (PJT) I, "Kajian Kapasitas Tampungan Waduk Sengguruh-Sutami- Lahor dan Wlingi-Lodoyo". Malang: Research by Berau of Research and Development PJT I, 2015.

[5] Nurdiyanto, L.M. Limantara, and E. Suhartanto. "Analisis Hujan dan Tata Guna Lahan Terhadap Limpasan Permukaan Di Sub DAS Pekalen, Kabupaten Probolinggo," Journal Of Water Resources Engineering, Vol. 7, No. 1, pp. 83-94, 2016. 
[6] M.N. Fikriy, L.M. Limantara, and E. Suhartanto. "CN Modeling for Predicting Discharge in Lesti Sub-watershed," Intl. Journal of Innovative Tech. and Exp. Eng, Vol. 8, Issue 12, pp 48904896, Oct 2019.

[7] A. Prakoso, S. Marsudi, and Sumiadi. "Analisis Laju Erosi Dan Usaha Konservasi Lahan Di Das Bogel Kabupaten Blitar Berbasis Sistem Informasi Geografis (SIG)," in Water Resources Engineering. Brawijaya University Website, [online document], 2016. Available: http:// pengairan.ub.ac.id/. [Accessed Januari 3, 2021].

[8] S. Tikno, T. Hariyanto, N. Anwar, A. Karsidi, and E. Aldrian. "Aplikasi Metode Curve Number Untuk Mempresentasikan Hubungan Curah Hujan Dan Aliran Permukaan Di DAS Ciliwung Hulu - Jawa Barat," Jurnal Tek. Ling, Vol. 13, No.1, pp. 25 - 36, Jan 2012.

[9] V.T. Chow, Hidrolika Saluran Terbuka, Jakarta : Erlangga, 1989.

[10] S.L. Neitsch, J.G. Arnold, J.R. Kiniry, R. Srinivasan, and J.R. Williams, Soil And Water Assessment Tool User's Manual Version 2000, Grassland, Soil and Water Research Lab. USDA Arigicultural Research Service, Temple, TX: Texas Water Resources Institute, 2002.

[11] E. Suhartanto, Panduan AVSWAT 2000 dan Aplikasinya di Bidang Teknik Sumber Daya Air, Malang: Asrori, 2008.

[12] E. Suhartanto, Panduan HEC-HMS dan Aplikasinya di Bidang Teknik Sumber Daya Air, Malang: Asrori, 2008.

[13] LM. Limantara, Hidrologi Praktis, Bandung: Lubuk Agung, 2010.

[14] Soewarno, Hidrologi Aplikasi Metode Statistik untuk Analisa Data, Bandung: Nova, 1995.

[15] Haribowo R., Andawayanti U., Lufira R.D. 2019. Effectivity test of an eco-friendly sediment trap model as a strategy to control erosion on agricultural land. Journal of Water and Land Development. No. 42 (VII-IX) p. 76-82. DOI: 10.2478/ jwld-2019-0047. 